\title{
The labor protection specialist competence influence on the professional risk management state
}

\author{
Elena Bakiko, ${ }^{1 *}$, Vitaly Serdyuk ${ }^{1}$, Svetlana Yanchij $^{1}$, Ivan Ignatovich $^{1}$ and Ekaterina Bardina $^{1}$ \\ ${ }^{1}$ Omsk State Technical University, Department of Industrial ecology and safety, 644050 Omsk, Russia
}

\begin{abstract}
The results of the authors' research in more than 600 organizations have shown the labor protection specialist competence influence on the occupational risk management system state and the overall labor protection management system. It is revealed that the leading role in the labor conditions and safety improving strategy choosing and formation, as well as in the scientifically based method of professional risk assessment belongs to a labor protection specialist with a certain competence. The paper describes 16 occupational safety specialists' professional competence levels and the main factors that determine their formation. The possibilities and abilities of specialists' with different professional competence levels to assess professional risks are considered and presented in tabular form. About 100 data of different approaches and methods for assessing occupational risks are given, from which only a competent occupational safety specialist can choose the best method for his organization. His decision influences not only the assessing and managing professional risks procedure costs, determined by the particular method choosing, but also the overall occupational safety management system effectiveness in the organization. The conducted research has shown a significant occupational safety competent specialists role in ensuring the professional risks management in the organization and allowed to link his capabilities in assessing professional risks with his professional competence level. This information can motivate the employer to pay attention to the labor protection specialists' role in ensuring the industrial safety and take care of their timely skills improvement.
\end{abstract}

\section{Introduction}

The risk-based approach to occupational health management in Russia is not just a motto of the future, but an existing reality. International experience shows that the production efficiency among other issues is aligned with occupational risks identification and management $[1,2]$. The existence and functioning of a modern occupational safety management system is a necessity for the employer and the regulatory authorities close attention subject. Its effectiveness depends directly on the professional risk management procedures integration.

The professional risk management system ensures workplace working conditions improvement, which leads to savings on non-production costs [3, 4].The successful workplace safety organization based on the occupational risk levels reduction is obvious [2, 5-7].

The leading role in the professional risk assessment and management organization is assigned to occupational safety specialists who do not always possess the necessary competence. Sometimes they are not sufficiently trained and are not actually able to organize an effective occupational risk management system in the company, because they do not have sufficient knowledge for this, which does not allow for an acceptable occupational safety management system functioning level. This circumstance testifies to the relevance of the working conditions and labor protection state dependence problem in the organization on the labor protection specialists' competence level studied by the authors.

\section{Methods}

The research used factor and statistical analysis methods, synthesis, method of principal components

The professional risk management system state studies in more than 600 organizations employing more than 1,000 occupational safety specialists in 18 regions of Russia, Western Siberia and the Khanty-Mansi Autonomous Area-YUGRA for the period 2017-2019 were conducted.

\section{Results}

The professional risk management system implementation in Russian organizations and its integration into occupational health and safety management systems, quality management systems and occupational safety and health management systems is an urgent task related to a number of methodological and

\footnotetext{
*Corresponding author: bakiko@mail.ru
} 
competency-based problems. Appropriate tools are needed to solve these problems and minimize risks.

In addition to the technical and technological factor of reducing occupational risks, it is necessary to take into account the human and organizational factors [8-10]. Competence potential as a tool for reducing the accidents number and severity is an axiom [11-14]. At this point the occupational safety specialists' professional competence becomes one of the main tools for effective occupational risks management.

The accumulated experience using in the professional risks assessing and managing in international companies has led to the practice of simple step-by-step procedures by safety managers in organizations. However, in the Russian legislation in the professional risk management methodology and its practice application field not all is unambiguously. Labor protection specialists face problems that are difficult or impossible to solve at the current level of their professional competence.

Therefore, the occupational safety specialists' assessment by the degree of readiness and ability to implement their competencies in the professional risks identification, assessment and management field, and their basic knowledge state can give employers and top managers the necessary tools to improve the professional risk management system effectiveness.

The competent occupational safety specialist role affects the organization strategy choosing and formation for working conditions and safety improving on the ground of scientifically based approach to professional risks managing.

The ambiguity of a professional risk assessment method choosing that is suitable for this industry and production activities specifics are explained by the following circumstances.

Firstly, there is no unified methodology in Russia, and at the same time a significant number of different methodological approaches to professional risk management are proposed. In such event, the employer has the right to choose an effective method for his production, but labor protection specialists have their first difficulties here. Today in Russia there are about 100 methods and approaches to professional risk assessment prepared and proposed for employers [15].

Professional risks are assessed:

- by direct and indirect method;

- using a qualitative, quantitative, or semiquantitative method;

-by normative, scientific and methodological, expert or international method;

- by the individual risks forecasting method, group risks forecasting method or the whole organization risks;

- by the individual method with or without account taken of employees personal data.

It is difficult for most occupational safety specialists to study them and choose the best one for their organization.

Secondly, there are still conceptual problems with risk assessment. The various methodology conceptual aspects increase the methods analyzing complexity and complexity of choosing the optimal one for implementation in production.
For example, risks are assessed in the occupational medicine context (employees health deterioration risk), in the safety context (industrial risks), in the labor protection context (occupational risks), in the social insurance fund context (organizational professional risk classes), in the effective management context (risk management).

At this stage, an insufficiently competent occupational safety specialist is aware of the lack of their basic professional knowledge and is not able to make the right decision that the employer needs [16].

This leads to a third group of problems - the competence group. The personality influence studies as the main factor in preventing accidents $[13,17]$ prove that effective professional risks management requires not only highly qualified managers, but also highly qualified labor protection specialists. Therefore, in addition to the methodological nature problems, according to the authors, there are problems associated with the low organizations labor protection specialists professional competence, on which the direct and leading participation in the effective professional risk management system organization for certain production depends.

According to the "Occupational Safety Specialist" professional standard occupational safety specialist of 6th qualification level should identify, analyze and manage professional risks in the organization; occupational safety specialist of 7th qualification level should evaluate the occupational safety and occupational risk management systems effectiveness, develop corrective actions, develop and improve the effectiveness of these systems. Thus, this professional standard also creates a need in high labor protection professional competence level specialists for organization.

The authors' research has shown that the occupational safety specialists' professional competence level in the organization in the field of determining occupational risks will depend on:

- labor protection specialist basic education;

-professional development, including identification and methodology of professional risk assessment;

- work experience as a labor protection specialist in the organization, including experience in the field of professional risk assessment;

- corporate standards and procedures for professional risk management systems;

- motivation of heads and managers at all levels in the company.

It is revealed that the labor protection specialists professional competence level, their work experience, ability to train and motivate organization's employees often determine the methodology choosing for assessing professional risks and the effectiveness of risk management. Also, the research conducted by the authors has shown that the leading factor in the professional competence formation is basic education.

The using of the author's 16-level of occupational safety specialists professional competence scale for managing occupational risks by the basic education factor is shown in table 1 . The conducted research 
allowed defining and describing the labor protection specialists' professional competence levels without taking into account the industry specifics of enterprises, the number of employees in the organization, the region where the enterprise is located, etc. (Table 1).

Table 1. Occupational safety specialists' professional competence levels.

\begin{tabular}{|c|c|}
\hline Level & $\begin{array}{l}\text { Labor protection specialists professional } \\
\text { competence main factors formation description }\end{array}$ \\
\hline 1 & $\begin{array}{l}\text { Higher education in "Technosphere safety" } \\
\text { (hereinafter referred to as occupational safety) } \\
\text { (postgraduate, doctoral studies), } \\
\text { labor protection specialist independent certification } \\
\text { (hereinafter referred to as certification) } \\
\text { and experience as a labor protection specialist for at } \\
\text { least } 3 \text { years }\end{array}$ \\
\hline 2 & $\begin{array}{l}\begin{array}{l}\text { Higher education in occupational } \\
\text { (postgraduate studies) and certification }\end{array} \\
\text { safety }\end{array}$ \\
\hline 3 & 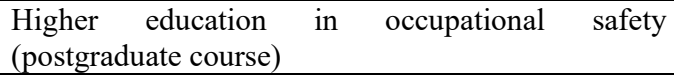 \\
\hline 4 & $\begin{array}{l}\text { Higher education in occupational safety (master's } \\
\text { degree) and certification }\end{array}$ \\
\hline 5 & $\begin{array}{l}\text { Higher education in occupational safety (master's } \\
\text { degree) }\end{array}$ \\
\hline 6 & $\begin{array}{l}\text { Higher education in occupational safety and } \\
\text { certification }\end{array}$ \\
\hline 7 & Higher education in occupational safety \\
\hline 8 & $\begin{array}{l}\text { Higher education in the sciences, additional } \\
\text { professional education (retraining) in occupational } \\
\text { safety and certification }\end{array}$ \\
\hline 9 & $\begin{array}{l}\text { Higher education in the sciences and additional } \\
\text { professional education (retraining) in labor safety }\end{array}$ \\
\hline 10 & $\begin{array}{l}\text { Higher education in the sciences and advanced } \\
\text { training }\end{array}$ \\
\hline 11 & $\begin{array}{l}\text { Higher education in the humanities, additional } \\
\text { professional education (retraining) in occupational } \\
\text { safety and certification }\end{array}$ \\
\hline 12 & $\begin{array}{l}\text { Higher education in the humanities, additional } \\
\text { professional education (retraining) in occupational } \\
\text { safety }\end{array}$ \\
\hline 13 & $\begin{array}{l}\text { Higher education in the humanities and advanced } \\
\text { training }\end{array}$ \\
\hline 14 & $\begin{array}{l}\text { Specialised secondary education, additional } \\
\text { professional education (retraining) in occupational } \\
\text { safety and experience as a labor protection } \\
\text { specialist for more than } 5 \text { years }\end{array}$ \\
\hline 15 & $\begin{array}{l}\text { Specialised secondary education, additional } \\
\text { professional education (retraining) in occupational } \\
\text { safety }\end{array}$ \\
\hline 16 & $\begin{array}{l}\text { Specialised secondary education and advanced } \\
\text { training }\end{array}$ \\
\hline
\end{tabular}

\section{Discussion}

As a result of researches conducted on the basis of Omsk State Technical University, it can be claimed that specialists in labor protection with a bachelor's degree will find it difficult to assess and manage professional risks in the organization. They will face both methodological and practical difficulties. For specialists with a master's degree, this task can be solved. However, practical experience in the organization is necessary. The occupational safety specialists' professional competence levels that will allow them to solve these tasks are presented in Table 2.

Table 2. Ability to manage professional risks.

\begin{tabular}{|c|c|c|c|}
\hline $\begin{array}{l}\text { Professional } \\
\text { competence } \\
\text { levels }\end{array}$ & $\begin{array}{l}\text { Levels' } \\
\text { estima } \\
\text { tion }\end{array}$ & $\begin{array}{l}\text { The analysis of } \\
\text { possibilities and } \\
\text { difficulties in } \\
\text { occupational } \\
\text { risks assessment }\end{array}$ & $\begin{array}{l}\text { Ability to } \\
\text { manage } \\
\text { professional } \\
\text { risks }\end{array}$ \\
\hline 1 & \multirow{5}{*}{ High } & & \multirow{2}{*}{$\begin{array}{c}\text { The specialist } \\
\text { is able to } \\
\text { manage } \\
\text { professional } \\
\text { risks }\end{array}$} \\
\hline 2 & & $\begin{array}{l}\text { It will not cause } \\
\text { any difficulties }\end{array}$ & \\
\hline 3 & & $\begin{array}{l}\text { It will not cause } \\
\text { any difficulties. } \\
\text { Practical } \\
\text { experience in } \\
\text { the organization } \\
\text { will be needed }\end{array}$ & $\begin{array}{l}\text { The specialist } \\
\text { is able to } \\
\text { manage } \\
\text { professional } \\
\text { risks by } \\
\text { having } \\
\text { experience }\end{array}$ \\
\hline 4 & & $\begin{array}{l}\text { Risk assessment } \\
\text { is possible }\end{array}$ & $\begin{array}{l}\text { The specialist } \\
\text { is able to } \\
\text { manage } \\
\text { professional } \\
\text { risks in } \\
\text { certain } \\
\text { circumstances }\end{array}$ \\
\hline 5 & & $\begin{array}{l}\text { Risk assessment } \\
\text { is possible. It } \\
\text { will cause } \\
\text { difficulties of } \\
\text { practical nature }\end{array}$ & \multirow{3}{*}{$\begin{array}{l}\text { The specialist } \\
\text { is able to } \\
\text { manage } \\
\text { professional } \\
\text { risks in } \\
\text { certain } \\
\text { circumstances } \\
\text {, but } \\
\text { difficulties } \\
\text { occur }\end{array}$} \\
\hline 6 & \multirow{3}{*}{ Medium } & $\begin{array}{c}\text { Risk assessment } \\
\text { is possible. It } \\
\text { will cause } \\
\text { difficulties of } \\
\text { methodological } \\
\text { nature } \\
\end{array}$ & \\
\hline 7 & & $\begin{array}{l}\text { Risk assessment } \\
\text { is possible. It } \\
\text { will cause } \\
\text { difficulties of } \\
\text { methodological } \\
\text { and practical } \\
\text { nature }\end{array}$ & \\
\hline 8 & & $\begin{array}{l}\text { Only formal risk } \\
\text { assessment can } \\
\text { be executed } \\
\text { (according to } \\
\text { sample) } \\
\end{array}$ & \multirow{8}{*}{$\begin{array}{l}\text { The specialist } \\
\text { is not able to } \\
\text { manage } \\
\text { professional } \\
\text { risks }\end{array}$} \\
\hline 10 & \multirow{4}{*}{ Low } & \multirow{4}{*}{$\begin{array}{l}\text { Risk assessment } \\
\text { is impossible }\end{array}$} & \\
\hline 11 & & & \\
\hline 12 & & & \\
\hline 13 & & & \\
\hline 14 & \multirow{3}{*}{\multicolumn{2}{|c|}{$\begin{array}{l}\text { The specialist is } \\
\text { incompetent in this field }\end{array}$}} & \\
\hline 15 & & & \\
\hline 16 & & & \\
\hline
\end{tabular}

Thus, the occupational safety specialists' professional competence directly affects the effectiveness of occupational safety and occupational risk management systems in the organization. Without 
higher education in "Technosphere safety", it is not possible to choose a scientifically based methodology and assess professional risks. Only professional retraining cannot give students the necessary competencies for this. In addition, the occupational safety specialist' qualification level, the form of training (full-time, part-time) and the training duration play a significant role.

The authors' research also showed:

- occupational safety specialists professional competence level is reduced by one step without regular and effective professional development;

- work experience from one year to 3 years increases the existing level by one step;

- work experience of more than 5 years simultaneously with regular and effective advanced training increases the professional competence level by two levels.

Thus, if the labor protection services specialists are assigned the assessment, analysis and effective risk management tasks, then the methodological complexity will consist in the scientifically-based choosing of appropriate methodology. There is a need to choose the optimal and effective method from a large list of authors' approaches recommended by various sources and international approaches for a particular organization. Therefore, the labor protection specialist professional competence should be of a high level.

Therefore, the labor protection services competence potential objective assessment and their professional competence improvement necessary range identification can serve as a tool for employers and top managers to improve the occupational risk management system effectiveness and the overall labor protection management system effectiveness in organizations.

\section{References}

[1] R. Ramesh, D.M. Prabu, S. Magibalan, P. Senthilkumar, Hazard Identification and Risk Assessment in Automotive Industry, International Journal of ChemTech Research 10, 4, 352-358 (2017).

[2] A.C. Ahmad, I.N.M. Zin, M.K. Othman, N.H. Muhamad, The 4th International Building Control Conference 2016 (IBCC 2016), Hazard Identification, Risk Assessment and Risk Control (HIRARC) Accidents at Power Plant, 00105, 66 (2016).

[3] M. Cioni, M. Savioli, Safety at the workplace: accidents and illnesses, Work, Employment and Society 30, 5, 858-875 (2016).

[4] E.V. Bakiko, V.S. Serdyuk, E.V. Yakovlev, Socio-economic impact of adverse working conditions and their differentiation, Omsk Scientific Bulletin, Series Society, History, Modernity 4, 4, 149-156 (2019).

[5] P. Carayon, P. Hancock, N. Leveson, I. Noy, L. Sznelwar, G. van. Hootegem, Advancing a sociotechnical systems approach to workplace safety developing the conceptual framework, Ergonomics 58, 4, 548-564 (2015).

[6] D.A. Hofmann, M.J. Burke, D. Zohar, 100 years of occupational safety research: From basic protections and work analysis to a multilevel view of workplace safety and risk, Journal of Applied Psychology 102, 3, 375-388 (2017).

[7] A.M. Lay, R. Saunders, M. Lifshen, F.C. Breslin, A.D. Lamontagne, E. Tompa, P.M. Smith, The relationship between occupational health and safety vulnerability and workplace injury, Safety Science 94, 85-93 (2017).

[8] M. Dağdeviren, İ. Yüksel, Developing a fuzzy analytic hierarchy process (AHP) model for behavior-based safety management, Information Sciences 178, 6, 1717-1733 (2008).

[9] J.E. Skogdalen, J.E. Vinnem, Quantitative risk analysis offshore - Human and organizational factors , Reliability Engineering \& System Safety 96, 4, 468-479 (2011).

[10] M.J. Djapan, D.P. Tadic, I.D. Macuzic, P.D. Dragojovic, A new fuzzy model for determining risk level on the workplaces in manufacturing small and medium enterprises, Proceedings of the Institution of Mechanical Engineers, Part O: Journal of Risk and Reliability 229, 5, 456-468 (2015).

[11] A. Badri, B. Boudreau-Trudel, A.S. Souissi, Occupational health and safety in the industry 4.0 era: A cause for major concern?, Safety Science 109, 403-411 (2018)

[12] G.C. Gauchard, J.M. Mur, C. Touron, L. Benamghar, D. Dehaene, P. Perrin, N. Chau, Determinants of accident proneness: a case-control study in railway workers, Occupational Medicine 56, 3, 187-190 (2006).

[13] S.P. Voroshilov, N.N. Novikov, G.Z. Feinburg, Fundamentals of the methodology for assessing the level of professional risk of an employee due to the level of his professional competence, Occupational health and safety in construction 5 (2011).

[14] A.M. Elin, Working conditions control as a managerial influence factor, Labor Protection and Economics 4, 17, 4-8 (2014).

[15] V.S. Serdyuk, A.M. Dobrenko, O.A. Tsorina, E.V. Bakiko, S.V. Yanchij, Mathematical models for estimating production risks, Journal of Physics: Conference Series, Mechanical Science and Technology Update (MSTU-2018) 1050, 012077 (2018).

[16] E.V. Bakiko, V.S. Serdyuk, V.V. Fadeeva, Organizational and economic aspect of labor protection specialist professional competence formation, Omsk Scientific Bulletin, Series Society, History, Modernity 5, 2, 160-168 (2020)

[17] E. Visser, Y.J. Pijl, R.P. Stolk, J. Neeleman, J.G.M. Rosmalen, Accident proneness, does it exist? A review and meta-analysis, Accident Analysis \& Prevention 39, 3, 556-564 (2007). 